MEDICAL

GENETICS

\title{
Publication-based analysis of miR-210 dependent biomarkers of pre-eclampsia
}

\section{Alexander Tkachenko ${ }^{1,2}$, Roman Illarionov ${ }^{1,3}$, Elena Vashukova ${ }^{1}$, and Andrei Glotov ${ }^{1,4}$}

${ }^{1}$ Department of Genomic Medicine, D. O. Ott Research Institute of Obstetrics, Gynecology and Reproductology, Mendeleyevskaya liniya, 3, Saint Petersburg, 199034, Russian Federation

${ }^{2}$ Computer Technologies Laboratory, ITMO University, Kronverkskiy pr., 49, Saint Petersburg, 197101, Russian Federation

${ }^{3}$ Department of Chemical and Biotechnology, Saint Petersburg State Technological Institute (Technical University), Moskovskiy pr., 26, Saint Petersburg, 190013, Russian Federation ${ }^{4}$ Laboratory of Biobanking and Genomic Medicine, Institute of Translational Biomedicine, Saint Petersburg State University, Universitetskaya nab., 7-9, Saint Petersburg, 199034, Russian Federation

Address correspondence and requests for materials to Andrei Glotov, anglotov@mail.ru

\begin{abstract}
MicroRNAs (miRNAs) are potential biomarkers of most pregnancy complications. In recent years, miR-210 has been shown as one of the main biomarkers, detected at different stages of pregnancy and associated with various diseases, including pre-eclampsia (PE). However, miR-210 is not reported as a marker of PE in about half of the studies. We filtered available published RNA-seq data and miRNAs associated with PE, including or excluding miR-210, obtained from the PregMiR database. For further analysis we only considered miRNAs appearing in at least four different studies. We observed that miR-152, miR-1 and miR-193b were only detected in studies with a changed miR-210 level, whereas miR-27a, miR-29a, miR-130a and miR-519b were detected in studies without miRNA-210 differential expression. Common biomarkers of PE are miR-182, miR-126, miR-155, miR-181a, miR-18a, miR-195, miR-21, miR-223, miR-335, miR517c, miR-518b, miR-518e and let-7f. Based on the obtained data and taking into account the direction of differential miRNA expression, it can be assumed that the most likely mechanisms of PE development in the early pregnancy stage are either upregulation of miR-210, miR-152, miR-518b and downregulation of miR-126; or upregulation of miR-126 and downregulation of miR-182 and miR518b. Late stages of PE are determined by miR-210, miR-152, miR-518b, miR-21, miR-155, miR-181a, miR-182, miR-193b-3p, miR-517c, miR-518e (upregulation) and miR-126, miR-18a, miR-195, miR-223, let-7f (downregulation); or miR-27a, miR-29a, miR-130a and miR-519d, miR-517c, miR-518e miR-155, miR-126, miR181a, miR-195 (upregulation) and miR-223, miR-18a, miR-182 (downregulation). The presented results allow speculation about the influence of certain miRNAs on PE development in the context of the presence or absence of miR-210 differential expression, but additional experimental studies are required to evaluate the findings.
\end{abstract}

Keywords: microRNA, pregnancy complications, miR-210, pre-eclampsia, bioinformatics analysis.

\section{Introduction}

Pre-eclampsia (PE) is a complication of pregnancy characterized by the onset of hypertension and proteinuria after 20 weeks of gestation. It is one of the leading causes of maternal and neonatal mortality and morbidity worldwide. Despite numerous studies, the origin and pathogenesis of PE remain unclear and accurate prognostic biomarkers of $\mathrm{PE}$ are lacking to date. There is evidence that $\mathrm{PE}$ is not a single disorder but a syndrome with many etiologies (Sibai, Dekker and Kupferminc, 2005).

Copyright: (c) 2020 Tkachenko et al. This is an open-access article distributed under the Petersburg State University, which permits self-archiving free of charge.

Funding: This study was financially supported by Russian Scientific Foundation, grant № 19-75-20033 (research, 
Short (21-25 nucleotides) noncoding RNAs, miRNAs negatively regulate gene expression by binding to the $3^{\prime}$-untranslated region of their target mRNAs (Mott and Mohr, 2015). Important roles are played by miRNAs in diverse biological processes, including pregnancy. Many studies have identified aberrant expression of different miRNAs in the placentas and blood from women with PE. Also, certain miRNAs were shown to be potential prognostic biomarkers for PE (Choi et al., 2013).

The most identified differentially expressed miRNA in PE is miR-210 - a hypoxia-responsive miRNA which is upregulated in many different types of cells under hypoxic conditions (Takizawa et al., 2012). The gene encoding miR-210 (MIR210) is located on the short arm of chromosome 11 (11p15.5) within the intron of long noncoding RNA AK123483. The MIR210 promoter contains binding sites of Hypoxia-Inducible Factor 1-alpha (HIF1a), which induces expression of miR-210 placenta, endothelium and trophoblast cells. Expression of MIR210 can be induced by Tumor Necrosis Factor alpha (TNFa), Nuclear Factor kappa B (NF- $\mathrm{B}$ ) and after activation of Toll-like Receptor 3 (TLR3). Targets of miR-210 are involved in mitochondrial metabolism, angiogenesis, DNA damage response, cell proliferation, and apoptosis (Bavelloni et al., 2017). Although miRNA-210 is most often mentioned in studies related to oncology, different pregnancy complications are associated with miRNA-210: gestational hypertension (Hromadnikova et al., 2017), gestational diabetes mellitus (Poirier, Desgagne, Guerin and Bouchard, 2017), and preterm birth (Östling, Kruse, Helenius and Lodefalk, 2019). In most studies (Pineles et al., 2007; Zhu et al., 2009; Enquobahrie et al., 2011; Gunel et al., 2011; Ishibashi et al., 2012; Betoni et al., 2013; Ura et al., 2014; Weedon-Fekjaer et al., 2014; Jiang et al., 2015; Li et al., 2015; Zhang et al., 2015; Munaut et al., 2016; Vashukova et al., 2016; Jairajpuri et al., 2017; Awamleh et al., 2019), miR-210 was found to be upregulated in the placenta, but miR-210 was also identified among differentially expressed miRNA in the plasma or serum of PE patients. Moreover, increased levels of miR-210 were detected in plasma samples before clinical manifestations of PE. However, miR-210 is not reported as a marker of $\mathrm{PE}$ in about half of the studies using both blood and placenta samples (Guo et al., 2009; Mayor-Lynn et al., 2011; Noack et al., 2011; Yang et al., 2011; Wang et al., 2012; Wu et al., 2012; Choi et al., 2013; Li et al., 2013; Akehurst et al., 2015; Yang et al., 2015; Sandrim et al., 2016; Gunel et al., 2017; Pei-Yin et al., 2017; Xu et al., 2017; Lykoudi et al., 2018; Martinez-Fierro et al., 2018; Timofeeva et al., 2018; Yoffe et al., 2018), so there is no clear understanding of regulatory pathways associated with miRNA-210 in PE.

The aim of our study is to compare and determine the influence of certain miRNAs on PE development in the context of the presence or absence of miR-210 differential expression. These findings may contribute to our understanding of molecular mechanisms involved in $\mathrm{PE}$ and identifying specific diagnostic markers for PE.

\section{Materials and methods}

Data analysis of miRNAs linked with preeclampsia. We obtained miRNAs linked with preeclampsia from the manually curated pregnancy pathology database PregMiR (https://pregmir.ott.ru/). We included miRNA genes in the analysis only if their differential expression between samples with preeclampsia and normal samples was significant (adjusted p-value $<0.05$ ). In order to compare gene regulation by miRNA in studies that list miR-210 among differentially expressed miRNA genes and studies that do not contain information about miR-210, we filtered the PregMiR database and further grouped miRNAs according to gestational age. We also performed a search for the identification of preeclampsia miRNA expression profiling studies. We undertook a web-based search in Gene Expression Omnibus (GEO, www.ncbi.nlm.nih.gov/geo/) using search term ("preeclampsia" [MeSH Terms] OR preeclampsia [All Fields]) AND "Homo sapiens" [porgn] AND ("Non-coding RNA profiling by array"[Filter] OR "Non-coding RNA profiling by high throughput sequencing" [Filter]). All the relevant studies were further reviewed manually to include studies of miRNA and no other types of noncoding RNAs. For further analysis we only considered miRNAs appearing in at least four different studies that used both blood and placenta samples.

Target genes prediction. Predicted targets for miRNAs were obtained from miRDB database v.6.0. Genes with target prediction score equal to 80 and above were included in further analysis.

GO enrichment analysis. $\mathrm{R}$ packages ClusterProfiler v.3.14.0 (Yu, Wang, Han and He, 2012) and DOSE 3.12.0 (Yu, Wang, Han and He, 2014) were applied to perform GO enrichment analysis (biological process terms), KEGG enrichment and DisGeNET enrichment analysis. In order to adjust p-values, false discovery rate (FDR) was calculated using the Benjamini and Hochberg method. FDR $<0.05$ was selected as the cutoff value for functional and pathway enrichment analysis of differentially expressed genes.

\section{Results and discussion}

\section{Base data analysis}

We conducted analysis of different studies with and without differential expression of miR-210 in PE. After filtering the data in the PregMiR database, we obtained 16 and 20 studies with and without differential expres- 


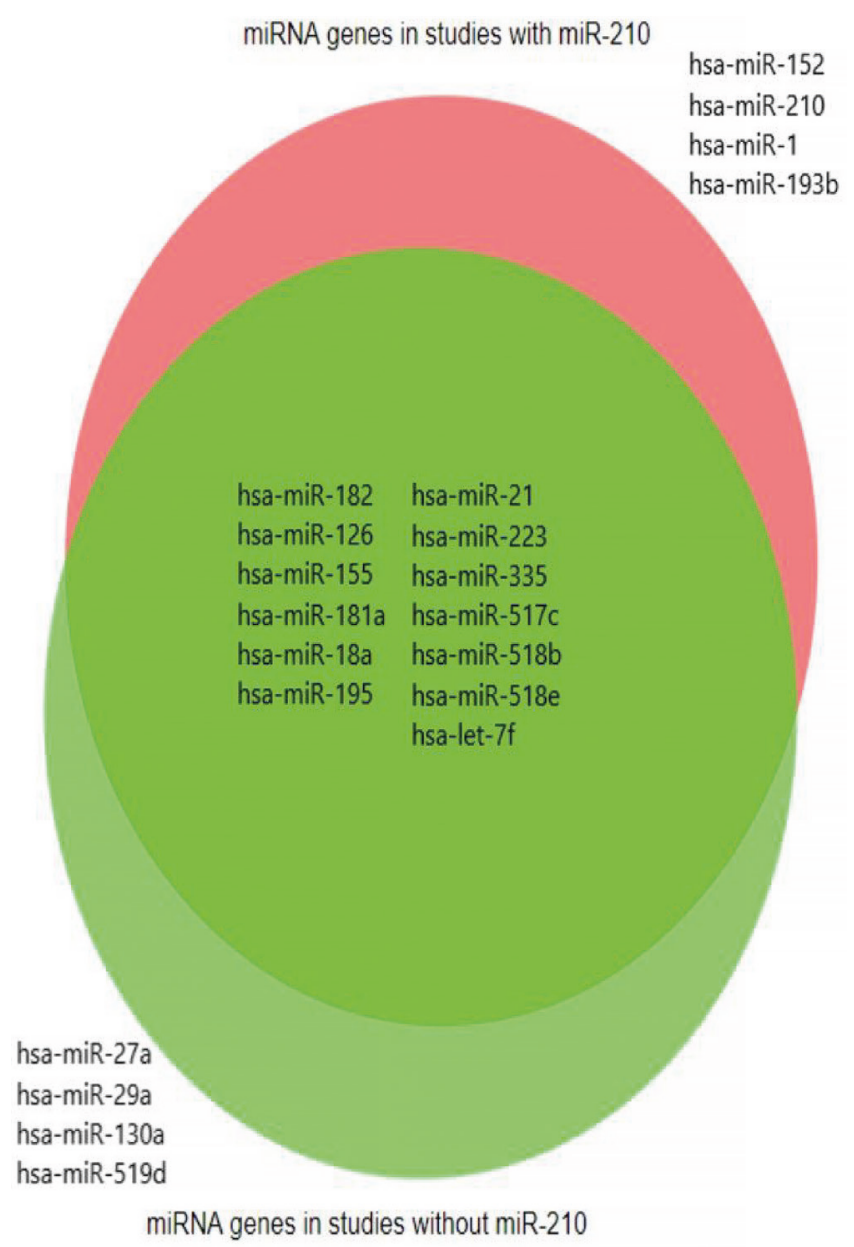

Fig. 1. Venn diagram of miRNAs appearing in at least four different studies of miRNA in preeclampsia.

sion of miRNA-210 in PE, respectively, at different stages of pregnancy.

The search for publicly available datasets for comparison of miRNA between preeclampsia and normotension resulted in four studies conducted with microarrays and three studies - with high-performance sequencing. Among the search results, only data from GSE114349 (RNA sequencing of miRNA from Azamleh et al., 2019) was included in Supplement 1, as other datasets did not have significantly differentially expressed genes (GSE103542, GSE96983), were already listed in PregMiR (GSE15789, GSE119799) or did not have an accompanying publication (GSE84260, GSE96983).

Most studies were performed with placental miRNAs; circulating miRNAs appeared in only 18 studies, with only 5 of them in the early stages of pregnancy. Placental miRNAs are not reliable biomarkers for pregnancy complications, as Menon et al. showed that miRNA expression changes during pregnancy (2018).

Combining data from PregMir and analysis of GEO data, we obtained 239 differentially expressed miRNAs in studies with miRNA-210 (Suppl. 1) and 126 - in studies without miR-210 differential expression re- ported (Suppl. 2), amounting to 320 unique miRNAs. Four different miRNA genes appeared in at least four different studies mentioning miR-210 and four miRNA genes - in studies without miR-210 in listed differential expression results, and 15 miRNAs appeared in both cases (Figure 1). Among them three miRNAs (miR-1, miR-193b, miR-195) were only differentially expressed in placenta samples and not in serum or plasma samples. Targets of these miRNAs were enriched in 32 and 79 KEGG pathways (89 for overlapping miRNAs appearing both in studies with and without miR-210 differential expression), 118 and 179 disease profiles from DisGeNET (147 for overlapping), 458 and 771 Gene Ontology biological process (815 for overlapping miRNAs) profiles for studies with and without miR-210, respectively. Dotplots for 15 most enriched gene lists are provided in Figure 2a-c.

Interestingly, only targets of miRNAs that are cooccurring with miR-210 in studies of pre-eclampsia are enriched in anoxia-associated genes (adjusted p-value 0.005 ), which is consistent with the hypoxia-related role of miR-210. Both RNA groups that appear with and without miR-210 context are associated with systemic arterial pressure (adjusted p-value $2.92^{\star} 10^{-9}$ ), as would be expected from PE markers.

\section{C19MC cluster}

Of these miRNAs, one miRNA (519d) in studies without miR-210 Yang et al., 2011; Li et al., 2013; Yang et al., 2015) and three (517c, 518b, 518e) in all studies (Zhu et al., 2009; Guo et al., 2011; Mayor-Lynn et al., 2011; Yang et al., 2011; Ishibashi et al., 2012; Li et al., 2013; Ura et al., 2014; Xu et al., 2014; Yang et al., 2015; Vashukova et al., 2016) were mapped to the C19MC cluster, the largest human miRNA gene cluster, whose expression is almost exclusively confined to the placenta. The cluster spans $\sim 100 \mathrm{~kb}$ on chromosome 19q13.41 and contains 54 predicted miRNA genes, 43 of which have been cloned and sequenced (Poirier et al., 2017). The C19MC cluster is regulated by genomic imprinting with only the paternally inherited allele being expressed in placenta, while the maternal one displays a methylation imprint (Poirier et al., 2017). The precise biological function of the C19MC cluster is unknown. It was shown that miRNAs of the C19MC have characteristics of oncogenes and may play a role in trophoblast cell proliferation, invasion, migration, intercellular communication and viral resistance (Poirier et al., 2017). It was reported that altered expression of $517 \mathrm{c}$ in the decidua is associated with recurrent pregnancy loss (Dong et al., 2014), and altered expression of miR-518b in the placenta-with low fetal birth weight (Ostling et al., 2019).

It is of note that the functioning of this cluster differs between two compared groups of miRNA studies 

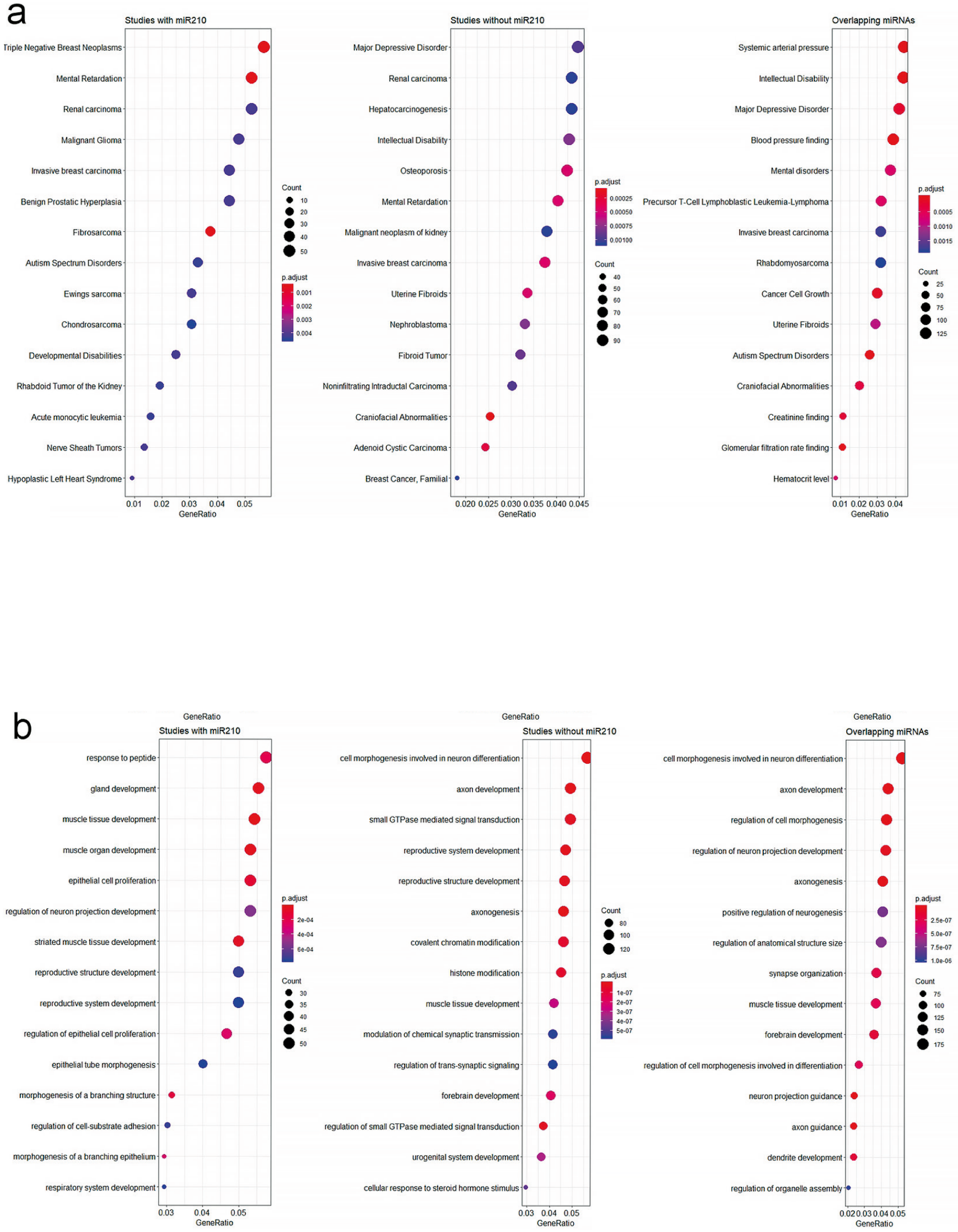


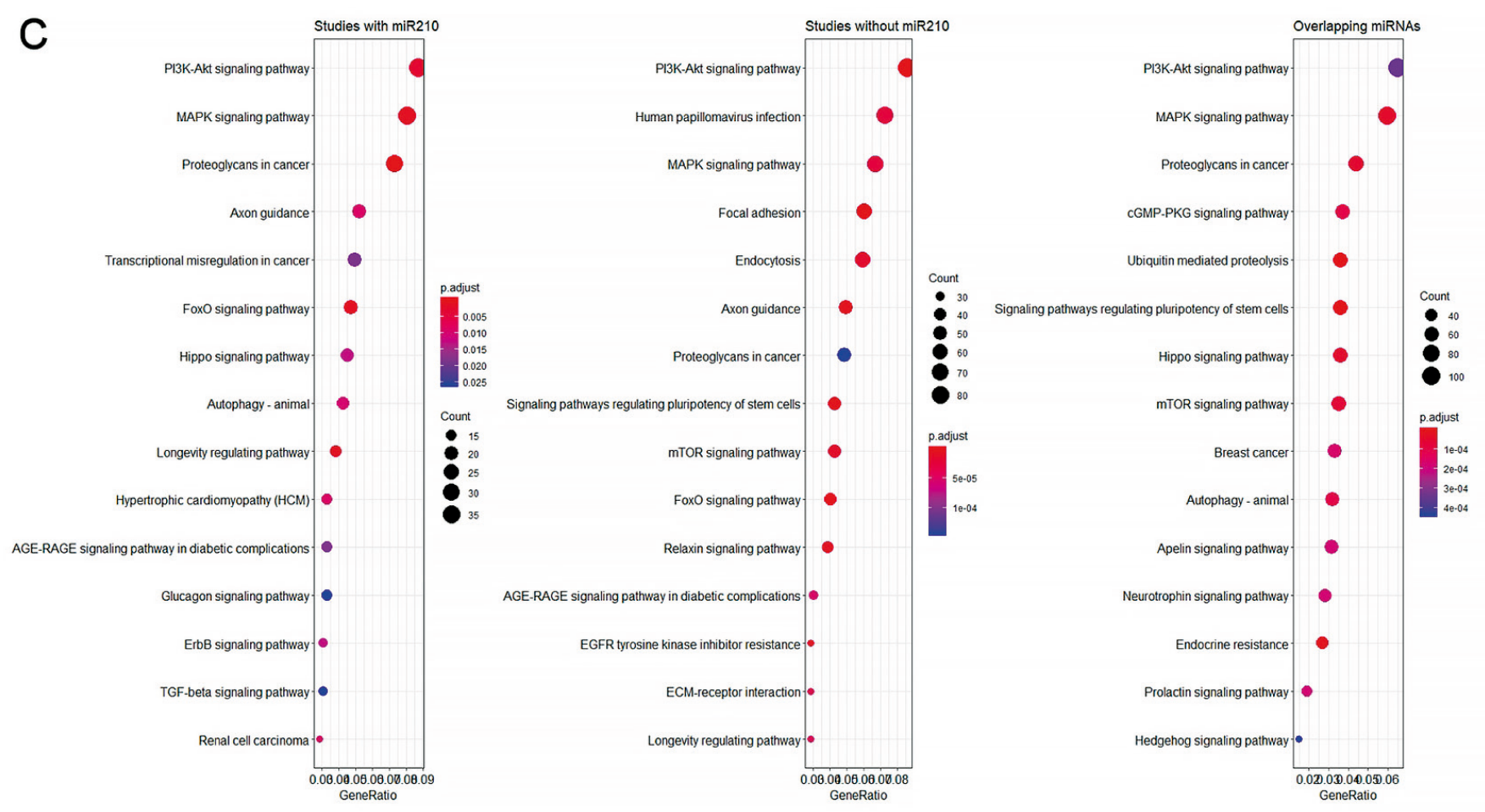

Fig. 2. a) Dotplot that depicts top 15 enriched DisGeNET pathways in miRNA targets of miRNA that do and do not co-occur with miR-210 in studies of preeclampsia. Dot sizes reflect sizes of gene sets, color corresponds to Bonferroni-Hochberg adjusted p-values. GeneRatio shows the proportion of miRNA target genes that are present in reference gene sets used to enrichment analysis. b-c) Same as a but for GO biological process and KEGG pathways, respectively.

in the direction of miR-518b expression change. In the context of miR-210 differential expression, miR-518b is upregulated in PE (Zhu et al., 2009; Ura et al., 2014; Xu et al., 2014) while it has decreased expression in studies where miR-210 levels are unchanged (Guo et al., 2011; Mayor-Lynn et al., 2011). This fact is important for understanding possible mechanisms of PE development, especially in early pregnancy terms when miR-518b is already detected in the plasma, as it can be used for routine screening of pregnant women according to changed miRNA expression profiles. It can be speculated that the risk group for PE is comprised of patients with upregulation of both miR-210 and miR-518b or downregulation of miR-518b on the background of unchanged miR210 expression level.

\section{miRNAs in studies with miR-210}

Among analyzed miRNAs, miR-152, miR-1, and miR$193 \mathrm{~b}$ are detected only in studies with miRNA-210. Upregulation of miR-152 is found in PE placentas (Zhu et al., 2009; Jiang et al., 2015) and blood serum from PE patients (Ura et al., 2014; Li et al., 2015). One of the targets of miR-152 is the HLA-G gene (Zhu et al., 2010). HLA-G protects trophoblast cells from lysis by Natural
Killer (NK) cells and contributes to the tolerance of the mother's immune system to the fetus (Zhu et al., 2010). A reduced level of $H L A-G$ mRNA was detected in PE placentas (Zhu et al., 2010). Overexpression of miR152 in trophoblast cells is associated with a reduction of HLA-G levels and increasing trophoblast lysis by NK cells (Zhu et al., 2010) that results in defective remodeling of uterine spiral arteries by the trophoblast. Also, miR-152 has been found to target placental growth factor (PLGF), which is synthesized in trophoblast cells and plays an important role in placental vessels development (Cai et al., 2016). In pregnancies complicated by PE, the level of PLGF is reduced (Cai et al., 2016).

Results about the expression of miR-1 are conflicted and inconsistent. In one study the level of miR-1 is increased (Zhang et al., 2015), while in others it is reduced in PE placentas (Zhu et al., 2009; Enquobahrie et al., 2011; Vashukova et al., 2016). It is possible that miR-1 affects the risk of PE development through its effect on calcium signaling (Enquobahrie et al., 2011) and through its influence on the expression of metallopeptidase inhibitor 3, which is involved in the regulation of trophoblast invasion (Lim et al., 2005; Xiang et al., 2013). Given the heterogeneous results and the lack of expression of this microRNA in early pregnancy stages 
and in blood samples, it is difficult to consider it as an important biomarker of PE.

In all reported studies miR-193b-3p is upregulated in PE placentas (Ishibashi et al., 2014; Xu et al., 2014; Vashukova et al., 2016; Awamleh et al., 2019). There were no studies where miR-193b differential expression was detected in blood samples. Overexpression of miR$193 \mathrm{~b}-3 \mathrm{p}$ represses proliferation, invasion, migration and growth of cancer cells (Zhou et al., 2016). In experiments in vitro, upregulation of miR-193b-3p has been found to inhibit the migration and invasion of trophoblast cells by targeting TGF- $\beta 2$ (transforming growth factor- $\beta$ ), which demonstrated significantly lower levels of mRNA and protein in PE placentas (Zhou et al., 2016).

\section{miRNAs in studies without miR-210}

The miRNAs miR-27a, miR-29a, miR-130a and miR$519 \mathrm{~d}$ were detected in more than four studies without miRNA-210 differential expression and are upregulated in all the studies reported here.

Upregulation of miR-27a was found in plasma and placental tissue in studies associated with PE (Hu et al., 2009; Li et al., 2013; Yang et al., 2015). Its gene is located on the chromosome 19p13.13. miR-27a is a member of the miR-23 $\sim 27 \sim 24$ cluster, participating in the process of angiogenesis by targeting angiogenesis inhibitor SEMA6A, which controls the repulsion of neighboring endothelial cells. miR-27a plays an anti-adipogenic role disrupting the function of mitochondria, and it is associated with angiogenesis in cardiovascular diseases and endothelial apoptosis in cardiac ischemia. Its role in inflammation is demonstrated by increased expression of pro-inflammatory cytokines, such as IL-10, when activated in TlR2 or TlR4-activated macrophages. It was also shown that the knockdown of miR-27a reduces the regulation of pro-inflammatory cytokines IL- 6 and TNF- $\alpha$, which are associated with PE (Maharaj et al., 2016).

The miR-29 family is associated with adult cardiovascular diseases, is expressed in human endothelium, and is involved in the process of angiogenesis. miR-29a is associated with pathways that are dysregulated in PE: the TGF- $\beta$ signaling pathway, estrogen signaling pathway, focal adhesion, and PI3K-Akt signaling pathway. Changes in these signaling pathways can lead to dysregulation of the endothelial function of the fetus, which is noted in PE (Zhou et al., 2017). In all studies reported here miR-29a was upregulated (Yang et al., 2011; Li et al., 2013; Yang et al., 2015), thus disrupting angiogenesis, causing dysregulation in the placentation.

A pro-angiogenic miRNA, miR-130a regulates homeobox proteins homeobox A5 (HOXA5) and growth arrest homeobox (GAX) (Chen and Gorski, 2007), which are involved in the development of the vascula- ture of the placenta. Research has shown that miR-130a attenuates endothelial cell damage by suppressing PTEN and activating the PI3K-Akt-NOS3 signaling pathway (Song et al., 2016). Increased regulation of miRNA-130a was found in all studies (Guo et al., 2011; Li et al., 2013; Yang et al., 2015), which suggests that it plays an important role in the pathogenesis of PE.

All of those miRNAs (miR-27a, miR-29a, miR-130a and miR-519d) were detected in plasma and placenta in later stages of pregnancy, which is probably due to their defined roles in the development of late PE forms.

\section{Overlapping miRNAs}

In most studies miR-223 is significantly downregulated in PE placentas (Zhu et al., 2009; Betoni et al., 2013; Choi et al., 2013; Weedon-Fekjaer et al., 2014; Xu et al., 2014; Vashukova et al., 2016;) and blood (Yang et al., 2011; $\mathrm{Li}$ et al., 2013). Only in two studies without miR-210, miR-223 was upregulated in the placenta (Guo et al., 2011; Mayor-Lynn et al., 2011). The expression of miR223 is regulated by several transcriptional factors, such as CCAAT-enhancer-binding proteins (C/EBP)- $\alpha$ and $-\beta$ and nuclear factor I-A (NFI-A) (Kapinas and Delany, 2011). Originally, miR-223 was characterized as a hematopoietic regulator that affects the development of hematopoietic stem cells, myeloid, erythroid and lymphoid cells (Johnnidis et al., 2008). Further studies have shown that miRNA-223 is involved in osteoclastogenesis (NFIA), granulopoiesis (IKKa, NF-IA, E2F), erythropoiesis (LMO2), cell invasiveness (MEF2C), tumor suppression (EPB4IL3), tumorigenesis (STMN1, FBW7, KRAS, EGF, EGFR2, MMP9, SEPTIN6), inflammation (NLRP3, Pknox1), glucose uptake (GLUT-4), VSMC proliferation (IGF-1R), and VSMC contractile phenotype (Rho B, MEF2C), which are associated with oncology, type 2 diabetes, cardiovascular diseases and diseases of the musculoskeletal system (Taïbi et al., 2014). There have also been studies where miR-223 is differentially expressed in various pregnancy complications, with the exception of PE, such as preterm birth (Mayor-Lynn et al., 2011; Tang et al., 2015; Enquobahrie et al., 2016; Gray et al., 2017; Winger et al., 2017; Menon et al., 2019).

Involvement and the mechanism of action of let- $7 \mathrm{f}$ in PE are still unclear. However, the role of let-7 family members in proliferation, apoptosis and inflammation suggests their contribution to the onset of PE via deregulation of these processes (Vashukova et al., 2016). In studies without miR-210, miR-let-7f was mostly downregulated (three cases out of five) (Yang et al., 2011; Li et al., 2013; Gunel et al., 2017) and was downregulated in the studies with miR-210 (Vashukova et al., 2016).

The miRNAs miR-335 and miR-21 are hypoxiaupregulated (Doridot et al., 2013). Jiang et al. (2015) has shown that miR-335 suppresses the migration and 
invasion of trophoblast cells by regulation of endothelial nitric oxide synthase (NOS3), which catalyzes the formation of nitric oxide (NO) from L-arginine in endothelial cells. NO is involved in trophoblast invasion, development and function of the placenta (Jiang et al., 2015). NOS3 has been identified as one of the susceptibility genes for PE. G894T (rs1799983) and T-786C (rs2070744) polymorphism in NOS3 predisposes to PE by decreasing the enzyme level and reducing the production of NO (Zeng et al., 2016). PE is associated with a decrease in the activity of NOS3, which leads to increased blood pressure (Zeng et al., 2016). However, the results of studies are conflicted, since in all studies, miRNA-335 increased and decreased in two cases (Hu et al., 2009; Ura et al., 2014; Jiang et al., 2015; Zhang et al., 2015). Therefore, the effect of miR-335 remains unclear.

miR-21 enhances trophoblast proliferation and invasion by modulating the nodal signaling pathway. Targets of miR-21 are VEGF and HIF- $1 \alpha$, which are involved in the regulation of angiogenesis. Research has shown that miR-21 also targets zinc finger transcription factor SP1, which is important in placental functions. SP1 controls the expression of cystathionine- $\gamma$ lyase (CSE), responsible for the synthesis of hydrogen sulfide (H2S), which has a vasodilator effect important for correct placentation (Doridot et al., 2013). During gestational diabetes mellitus (Wander et al., 2017) and pregnancy-induced hypertension complicated with heart failure (Kan et al., 2019), miR-21 is differentially expressed. Sanders et al. (2015) showed that miR-21, isolated from cervical cells, was significantly overexpressed in women who had a shorter gestation. The expression of miRNA-21 was increased in all studies with miRNA-210 (Jiang et al., 2015; Jairajpuri et al., 2017), and studies have produced contradictory results (one upregulated (Li et al., 2013) and two downregulated (Choi et al., 2013; Gunel et al., 2017)).

An important role in angiogenesis is played by miR126 and miR-155 by enhancing the function of vascular endothelial growth factor VEGF. Targets of miR-126 are phosphoinositide-3-kinase regulatory subunit 2 (PIK3R2) and sprouty-related EVH1 domain, containing protein 1 (SPRED1), which downregulate VEGF via MAP kinase and PI3 pathways (Hong, Li and $\mathrm{Xu}, 2014$ ). miR-155 binds to the 3' UTR region of CYR61 (cysteinerich protein 61), inducing VEGF (Zhung et al., 2014). It was shown that VEGF is also involved in the regulation of trophoblast invasion, proliferation and differentiation. (Shore et al., 1997). Interestingly, in studies with miR-210, miR-126 was downregulated in three cases out of four (Zhu et al., 2009; Ishibashi et al., 2012; Ura et al., 2014), and in studies without miR-210, it was upregulated in four cases out of five (Hu et al., 2009; Guo et al., 2011; Yang et al., 2015; Lykoudi et al., 2018). It can be assumed that in these cases, the pathogenesis of PE oc- curs via different pathways. In all studies, miR-155 was upregulated ( Pineles et al., 2007; Lykoudi et al., 2015; Xu et al., 2015; Jairajpuri et al., 2017).

A member of the miRNA 17-92 cluster, miR-18a is involved in the regulation of trophoblast cell activity. The target for miRNA-18a is Smad2, associated with TGF- $\beta$ signaling, which modulates trophoblast cell invasion (Xu et al., 2014). Also, miRNA-18a regulates the expression of estrogen receptor $\alpha-3^{\prime}$ (ESR $\left.\alpha-3^{\prime}\right)$, which is involved in trophoblast apoptosis (Zhu et al., 2015). As in the case of miR-126, miR-18a has different regulation between studies with (downregulation) and without (upregulation) miR-210 (Zhu et al., 2009; Li et al., 2013; Xu et al., 2014; Yang et al., 2015; Vashukova et al., 2016; Jairajpuri et al., 2017).

Also, miR-182 affects trophoblast invasion via binding to RND3 3' UTR region (Fang et al., 2018). It is possible that miR-182 plays a role as an immune response enhancer by stimulation of $\mathrm{T}$ helper cells via upregulation of IL-2 (Serebelli, Satoh and Chan, 2012). In one of eight studies (the list without miR-210), miR-182 was downregulated in plasma in early terms (Yoffe et al., 2018); in the rest of the studies (Pineles et al., 2007; Noack et al., 2011; Jiang et al., 2015; Li et al., 2015; Zhang et al., 2015) it was increased, which allows us to make an assumption about the importance of miR-182 in PE.

SPP1 and ITGB3, which are targets for miR-181a, are components of the focal adhesion signal pathway. Focal adhesions are dynamic macromolecular complexes comprised of integrins which bind the extracellular matrix (ECM) to the actin cytoskeleton and have been demonstrated to play an important role in embryo implantation and placentation. Many of the components of the focal adhesion signal pathway link integrin-mediated signals with other signaling pathways, such as mTOR, PI3K, and MAPK signaling pathways (Su et al., 2014). Additionally, miR-181a is involved in the invasion and migration of trophoblasts via deregulation of insulin-like growth factor 2 mRNA-binding protein 2 (IGF2BP2) (Wu et al., 2018). In all studies, miR-181a was upregulated (Hu et al., 2009; Zhu et al., 2009; Wu et al., 2012; Jiang et al., 2015; Zhang et al., 2015; Awamleh et al., 2019). Given its relationship with pathways involved in PE, miR-181a can be considered a potential biomarker of PE.

Involvement of miR-195 occurs in inhibition of cell invasion and migration (FASN, CCNE1), inhibition of cell proliferation (HSPA4L, CCNE1, AKT3), angiogenesis and inhibition of trophoblast invasion (VEGF), vascular homeostasis (SMURF1), trophoblast apoptosis and cell cycle control (WEE1), which lead to impaired placentation and, therefore, to PE (Gunel et al., 2018). The difference in the expression of miR-195 in studies associated and unassociated with miR-210 suggests different mechanisms of PE in two groups of studies. 
Differential expression of miR-195 was found only in placenta samples where it was downregulated in studies with miR-210 (Zhu e al., 2009; Xu et al., 2014; Vashukova et al., 2016), and upregulated in studies without miR-210 (Hu et al., 2009).

\section{Conclusion}

The search for new biomarkers of severe pregnancy complications remains a relevant task. Different miRNAs are among promising candidates for biomarkers of pregnancy complications. One of the most popular biomarkers, miR-210, is a hypoxia-responsive miRNA which is associated with various pregnancy complications including $\mathrm{PE}$, gestational diabetes, preterm birth and others (Hromadnikova et al., 2017; Poirier, Desgagne, Guerin and Bouchard, 2017; Östling, Kruse, Helenius and Lodefalk, 2019). However, miR-210 is not reported as a marker of $\mathrm{PE}$ in about half of the studies, which may indicate the presence of different pathogenetic mechanisms of $\mathrm{PE}$ development.

Here we have shown that targets of miRNAs cooccurring with miR-210 in studies of PE are enriched in anoxia-associated genes, which is consistent with the hypoxia-related role of miR-210. All reviewed studies report miR-152 co-expression with miR-210. Research has found miR-152 to target placental growth factor (PLGF), the main biomarker of PE, which is synthesized in trophoblast cells and plays an important role in placental angiogenesis (Cai et al., 2016). Apparently, these mechanisms of pathogenesis of $\mathrm{PE}$ have a common basis. This suggests that both miR-210-associated biomarkers and PLGF can serve as predictors of early PE. On the other hand, at least half of the cases of $\mathrm{PE}$ require additional biomarkers. Therefore, our study aims to determine the effect of certain miRNAs on PE development in the context of the presence or absence of miR-210 differential expression.

Based on data from studies of miRNA expression, we can assume several different mechanisms of PE development. The first is related to early detection of upregulated miR-210 and co-expressed miR-152, miR-518b and downregulation of miR-126 in plasma of pregnant women followed by upregulation of miR-21, miR-155, miR-181a, miR-182, miR-193b-3p, miR-517c and miR$518 \mathrm{e}$ and downregulation of miR-18a, miR-195, miR223 and let-7f in placentas in later stages. The second mechanism of PE development may be associated with detection of such biomarkers as miR-126 (upregulated) and miR-182, miR-518b (downregulated) in blood plasma in early pregnancy. And the third mechanism is apparently determined by changes of specific miRNAs not associated with miR-210 in late stages of pregnancy: miR-27a, miR-29a, miR-130a and miR-519d (upregulated); and common biomarkers: miR-517c, miR-518e,
miR-155, miR-126, miR-181a, miR-195 (upregulated) and miR-223, miR-18a, miR-182 (downregulated).

Currently there are few studies of miRNA-seq on early stages of pregnancy. We understand that this study is theoretical in nature. All of this is a certain limitation of the work and our findings need to be tested in experimental studies. However, despite this we believe that our results elucidate the mechanisms of PE pathogenesis and can be useful in screening programs in the future.

\section{Acknowledgments}

This study was financially supported by Russian Scientific Foundation, grant № 19-75-20033 (research, bioinformatics) and D. O. Ott Research Institute of Obstetrics, Gynecology and Reproductology, project № 0558-2017-0056 (support of PregMiR database).

\section{References}

Awamleh, Z., Gloor, G. B., and Han, V. K. M. 2019. Placental microRNAs in pregnancies with early onset intrauterine growth restriction and preeclampsia: Potential impact on gene expression and pathophysiology. BMC Medical Genomics 12:1-10. https://doi.org/10.1186/s12920-0190548-x

Bavelloni, A., Ramazzotti, G., Poli, A., Piazzi, M., Focaccia, E., Blalock, W., and Faenza, I. 2017. Mirna-210: A current overview. Anticancer Research 37:6511-6521. https://doi. org/10.21873/anticanres.12107

Betoni, J. S., Derr, K., Pahl, M. C., Rogers, L., Muller, C. L., Packard, R. E., Carey, D.J., Kuivaniemi, H., and Tromp, G. 2013. MicroRNA analysis in placentas from patients with preeclampsia: Comparison of new and published results. Hypertension in Pregnancy 32:321-339. https://doi. org/10.3109/10641955.2013.807819

Cai, M., Wang, K., and Ahmed, A., Preeclampsia, Pub, no. WO/2016/151287. Int. Appl., no. PCT/GB2016/050710, 2016.

Ceribelli, A., Satoh, M., and Chan, E. K. L. 2012. MicroRNAs and autoimmunity. Current Opinion in Immunology 24:686691. https://doi.org/10.1016/j.coi.2012.07.011

Chen, Y. and Gorski, D. H. 2008. Regulation of angiogenesis through a microRNA (miR-130a) that downregulates antiangiogenic homeobox genes GAX and HOXA5. Blood 111:1217-1226. https://doi.org/10.1182/ blood-2007-07-104133

Choi, S. Y., Yun, J., Lee, O. J., Han, H. S., Yeo, M. K., Lee, M. A., and Suh, K. S. 2013. MicroRNA expression profiles in placenta with severe preeclampsia using a PNA-based microarray. Placenta 34:799-804. https://doi.org/10.1016/j. placenta.2013.06.006

Dong, F., Zhang, Y., Xia, F., Yang, Y., Xiong, S., Jin, L., and Zhang, J. 2014. Genome-wide miRNA profiling of villus and decidua of recurrent spontaneous abortion patients. Reproduction 1481:33-41. https://doi.org/10.1530/rep14-0095

Enquobahrie, D. A., Hensley, M., Qiu, C., Abetew, D. F., Hevner, K., Tadesse, M. G., and Williams, M. A. 2016. Candidate gene and microRNA expression in fetal membranes and preterm delivery risk. Reproductive Sciences 23:731737. https://doi.org/10.1177/1933719115612925

Enquobahrie, D. A., Meller, M., Rice, K., Psaty, B. M., Siscovick, D. S., and Williams, M. A. 2008. Differential placental gene expression in preeclampsia. American Journal of 
Obstetrics and Gynecology 199:566.e1-566.e11. https:// doi.org/10.1016/j.ajog.2008.04.020

Fang, Y. N., Huang, Z. L., Li, H., Tan, W. B., Zhang, Q. G., Wang, L., and Wu, J. L. 2018. Highly expressed miR-182-5p can promote preeclampsia progression by degrading RND3 and inhibiting HTR-8/SVneo cell invasion. European review for medical and pharmacological sciences 22:6583-6590. https://doi.org/10.26355/eurrev_201810_16132

Gray, C., McCowan, L. M., Patel, R., Taylor, R. S., and Vickers, M. H. 2017. Maternal plasma miRNAs as biomarkers during mid-pregnancy to predict later spontaneous preterm birth: A pilot study. Scientific Reports 7:1-7. https:// doi.org/10.1038/s41598-017-00713-8

Gunel, T., Kamali, N., Hosseini, M. K., Gumusoglu, E., Benian, A., and Aydinli, K. 2018. Regulatory effect of miR-195 in the placental dysfunction of preeclampsia. The Journal of Maternal-Fetal and Neonatal Medicine 33(6):901-908. https://doi.org/10.1080/14767058.2018.1508439

Gunel, T., Zeybek, Y. G., Akçakaya, P., Kalelioğlu, I., Benian, A., Ermis, H., and Aydınlı, K. 2011. Serum microRNA expression in pregnancies with preeclampsia. Genetics and Molecular Research 10:4034-4040. https://doi. org/10.4238/2011.November.8.5

Gunel, T., Hosseini, M. K., Gumusoglu, E., Kisakesen, H. I., Benian, A., and Aydinli, K. 2017. Expression profiling of maternal plasma and placenta microRNAs in preeclamptic pregnancies by microarray technology. Placenta 52:7785. https://doi.org/10.1016/j.placenta.2017.02.019

Guo, L., Yang, Q., Lu, J., Li, H., Ge, Q., Gu, W., Bai, Y., and Lu, Z. 2011. A comprehensive survey of miRNA repertoire and 3 ' addition events in the placentas of patients with preeclampsia from high-throughput sequencing. PLOS ONE 6. https://doi.org/10.1371/journal.pone.0021072

Hong, F., Li, Y., and Xu, Y. 2014. Decreased placental miR126 expression and vascular endothelial growth factor levels in patients with pre-eclampsia. Journal of International Medical Research 42:1243-1251. https://doi. org/10.1177/0300060514540627

Hromadnikova, I., Kotlabova, K., Ivankova, K., Vedmetskaya, Y., and Krofta, L. 2017. Profiling of cardiovascular and cerebrovascular disease associated microRNA expression in umbilical cord blood in gestational hypertension, preeclampsia and fetal growth restriction. International Journal of Cardiology 249:402-409. https://doi. org/10.1016/j.ijcard.2017.07.045

Hu, Y., Li, P., Hao, S., Liu, L., Zhao, J., and Hou, Y. 2009. Differential expression of microRNAs in the placentae of Chinese patients with severe pre-eclampsia. Clinical Chemistry and Laboratory Medicine 47:923-929. https:// doi.org/10.1515/CCLM. 2009.228

Jairajpuri, D. S., Malalla, Z. H., Mahmood, N., and Almawi, W. Y. 2017. Circulating microRNA expression as predictor of preeclampsia and its severity. Gene 627:543-548. https://doi.org/10.1016/j.gene.2017.07.010

Jiang, F., Li, J., Wu, G., Miao, Z., Lu, L., Ren, G., and Wang, X. 2015. Upregulation of microRNA-335 and microRNA-584 contributes to the pathogenesis of severe preeclampsia through downregulation of endothelial nitric oxide synthase. Molecular Medicine Reports 12:5383-5390. https:// doi.org/10.3892/mmr.2015.4018

Johnnidis, J. B., Harris, M. H., Wheeler, R. T., Stehling-Sun, S., Lam, M. H., Kirak, O., Brummelkamp, T.R., Fleming, M. D., and Camargo, F. D. 2008. Regulation of progenitor cell proliferation and granulocyte function by microRNA-223. Nature 451:1125-1129. https://doi. org/10.1038/nature06607

Kan, C., Cao, J., Hou, J., Jing, X., Zhu, Y., Zhang, J., Guo, Y., and Chen, X. 2019. Correlation of miR-21 and BNP with preg- nancy-induced hypertension complicated with heart failure and the diagnostic value. Experimental and Therapeutic Medicine 17(4):3129-3135. https://doi.org/10.3892/ etm.2019.7286

Kilby, M. 2011. Pre-eclampsia is a risk marker. BMJ 342:d1631. https://doi.org/10.1136/bmj.d1631

Kapinas, K. and Delany, A. M. 2011. MicroRNA biogenesis and regulation of bone remodeling. Arthritis Research and Therapy 13:1-11. https://doi.org/10.1186/ar3325

Li, H., Ge, Q., Guo, L., and Lu, Z. 2013. Maternal plasma miRNAs expression in preeclamptic pregnancies. BioMed Research International. https://doi.org/10.1155/2013/970265

Li, Q., Long, A., Jiang, L., Cai, L., Xie, L., Gu, J., Chen, X., and Tan, L. 2015. Quantification of preeclampsia-related microRNAs in maternal serum. Biomedical Reports 3:792796. https://doi.org/10.3892/br.2015.524

Lim, L. P., Lau, N. C., Garrett-Engele, P., Grimson, A., Schelter, J. M., Castle, J., Bartel, D. P., Linsley, P. S., and Johnson, J. M. 2005. Microarray analysis shows that some microRNAs downregulate large numbers of-target mRNAs. Nature 433:769-773. https://doi.org/10.1038/ nature03315

Lykoudi, A., Kolialexi, A., Lambrou, G. I., Braoudaki, M., Siristatidis, C., Papaioanou, G. K., Tzetis, M., Mavrou, A., and Papantoniou, N. 2018. Dysregulated placental microRNAs in early and late onset preeclampsia. Placenta 61:24-32. https://doi.org/10.1016/j.placenta.2017.11.005

Maharaj, N. R., Ramkaran, P., Pillay, S., and Chuturgoon, A. A. 2016. microRNA-27a rs895819 is associated with obesity in HIV infected preeclamptic Black South African women on HAART. BMC Medical Genetics 17:1-8. https://doi. org/10.1186/s12881-016-0353-8

Martinez-Fierro, M. L., Garza-Veloz, I., Gutierrez-Arteaga, C., Delgado-Enciso, I., Barbosa-Cisneros, O.Y., FloresMorales, V., Hernandez-Delgadillo, G.P., Rocha-Pizaña, M. R., Rodriguez-Sanchez, I.P., Badillo-Almaraz, J. I., Ortiz-Rodriguez, J. M., Castañeda-Miranda, R., Solis-Sanchez, L. O., and Ortiz-Castro, Y. 2018. Circulating levels of specific members of chromosome 19 microRNA cluster are associated with preeclampsia development. Archives of Gynecology and Obstetrics 297:365-371. https://doi. org/10.1007/s00404-017-4611-6

Mayor-Lynn, K., Toloubeydokhti, T., Cruz, A.C., and Chegini, N. 2011. Expression profile of microRNAs and mRNAs in human placentas from pregnancies complicated by preeclampsia and preterm labor. Reproductive Sciences 18:46-56. https://doi.org/10.1177/1933719110374115

Menon, R., Debnath, C., Lai, A., Guanzon, D., Bhatnagar, S., Kshetrapal, P. K., Sheller-Miller, S., and Salomon, C. 2019. Circulating exosomal miRNA profile during term and preterm birth pregnancies: A longitudinal study. Endocrinology 160:249-275. https://doi.org/10.1210/en.201800836

Mohr, A. M. and Mott, J. L. 2015. Overview of microRNA biology. Seminars in Liver Disease 35:3-11. https://doi. org/10.1055/s-0034-1397344

Munaut, C., Tebache, L., Blacher, S., Noël, A., Nisolle, M., and Chantraine, F. 2016. Dysregulated circulating miRNAs in preeclampsia. Biomedical Reports 5:686-692. https://doi. org/10.3892/br.2016.779

Noack, F., Ribbat-Idel, J., Thorns, C., Chiriac, A., Axt-Fliedner, R., Diedrich, K., and Feller, A. C. 2011. miRNA Expression profiling in formalin-fixed and paraffin-embedded placental tissue samples from pregnancies with severe preeclampsia. Journal of Perinatal Medicine 39:267-271. https://doi.org/10.1515/JPM.2011.012

Östling, H., Kruse, R., Helenius, G., and Lodefalk, M. 2019. Placental expression of microRNAs in infants born 
small for gestational age. Placenta 81:46-53. https://doi. org/10.1016/j.placenta.2019.05.001

Pineles, B. L., Romero, R., Montenegro, D., Tarca, A. L., Han, Y. M., Kim, Y. M., Draghici, S., Espinoza, J., Kusanovic, J. P., Mittal, P., Hassan, S. S., and Kim, C. J. 2007. Distinct subsets of microRNAs are expressed differentially in the human placentas of patients with preeclampsia. American Journal of Obstetrics and Gynecology 196:261. e1-261.e6. https://doi.org/10.1016/j.ajog.2007.01.008

Poirier, C., Desgagné, V., Guérin, R., and Bouchard, L. 2017. MicroRNAs in pregnancy and gestational diabetes mellitus: emerging role in maternal metabolic regulation. Current Diabetes Reports 17. https://doi.org/10.1007/ s11892-017-0856-5

Sanders, A. P., Burris, H. H., Just, A. C., Motta, V., Svensson, K., Mercado-Garcia, A., Pantic, I., Schwartz, J., Tellez-Rojo, M. M., Wright, R. O., and Baccarelli, A. A. 2015. microRNA expression in the cervix during pregnancy is associated with length of gestation. Epigenetics 10(3):221-228. https://doi.org/10.1080/15592294.2015.1006498

Sandrim, V. C., Luizon, M. R., Palei, A. C., Tanus-Santos, J. E., and Cavalli, R.C. 2016. Circulating microRNA expression profiles in pre-eclampsia: evidence of increased miR-885-5p levels. BJOG: an international journal of obstetrics and gynaecology 123:2120-2128. https://doi. org/10.1111/1471-0528.13903

Shore, V. H., Wang, T. H., Wang, C. L., Torry, R. J., Caudle, M. R., and Torry, D. S. 1997. Vascular endothelial growth factor, placenta growth factor and their receptors in isolated human trophoblast. Placenta 18:657-665. https:// doi.org/10.1016/S0143-4004(97)90007-2

Song, C., Liu, B., Shi, Y., Liu, N., Yan, Y., and Zhang, J. 2016. MicroRNA-130a alleviates human coronary artery endothelial cell injury and inflammatory responses by targeting PTEN via activating PI3K / Akt / eNOS signaling pathway. Oncotarget 44:71922-71936. https://doi. org/10.18632/oncotarget.12431

Su, L., Liu, R., Cheng, W., Zhu, M., Li, X., Zhao, S., and Yu, M. 2014. Expression patterns of microRNAs in porcine endometrium and their potential roles in embryo implantation and placentation. PLOS ONE 9. https://doi. org/10.1371/journal.pone.0087867

Takizawa, T., Ishibashi, O., Ohkuchi, A., Moksed, A. M., Kurashina, R., Luo, S. S., Ishikawa, T., Takizawa, T., Hirashima, C., Takahashi, K., Migita, M., Ishikawa, G., Yoneyama, K., Asakura, H., Izumi, A., Matsubara, S., and Takeshita, T. 2012. Hydroxysteroid (17- $\beta$ ) dehydrogenase 1 is dysregulated by miR-210 and miR-518c that are aberrantly expressed in preeclamptic placentas: A novel marker for predicting preeclampsia. Hypertension 59:265-273. https://doi.org/10.1161/HYPERTENSIONAHA.111.180232

Taïbi, F., Metzinger-Le, M. V., Massy, Z. A., and Metzinger, L. 2014. MiR-223: An inflammatory oncomiR enters the cardiovascular field. Biochimica et Biophysica Acta Molecular Basis of Disease 1842:1001-1009. https://doi. org/10.1016/j.bbadis.2014.03.005

Tang, Y., Ji, H., Liu, H., Gu, W., Li, X., and Peng, T. 2015. Identification and functional analysis of microRNA in myometrium tissue from spontaneous preterm labor. International Journal of Clinical and Experimental Pathology 8(10):12811-12819.

Timofeeva, A. V., Gusar, V. A., Kan, N. E., Prozorovskaya, K. N., Karapetyan, A. O., Bayev, O.R., Chagovets, V.V., Kliver, S. F., lakovishina, D. Y., Frankevich, V. E., and Sukhikh, G. T. 2018. Identification of potential early biomarkers of preeclampsia. Placenta 61:61-71. https://doi. org/10.1016/j.placenta.2017.11.011
Tsai, P. Y., Li, S. H., Chen, W. N., Tsai, H. L., and Su, M. T. 2017. Differential miR-346 and miR-582-3p expression in association with selected maternal and fetal complications. International Journal of Molecular Sciences 18. https://doi. org/10.3390/ijms18071570

Ura, B., Feriotto, G., Monasta, L., Bilel, S., Zweyer, M., and Celeghini, C. 2014. Potential role of circulating microRNAs as early markers of preeclampsia. Taiwanese Journal of Obstetrics and Gynecology 53:232-234. https://doi. org/10.1016/j.tjog.2014.03.001

Vashukova, E.S., Glotov, A.S., Fedotov, P. V., Efimova, O. A., Pakin, V.S., Mozgovaya, E. V., Pendina, A.A., Tikhonov, A. V., Koltsova, A. S., and Baranov, V. S. 2016. Placental microRNA expression in pregnancies complicated by superimposed pre-eclampsia on chronic hypertension. Molecular Medicine Reports 14:22-32. https://doi. org/10.3892/mmr.2016.5268

Wang, W., Feng, L., Zhang, H., Hachy, S., Satohisa, S., Laurent, L. C., Parast, M., Zheng, J., and Chen, D. B. 2012. Preeclampsia up-regulates angiogenesis-associated microRNA (i.e., miR-17, -20a, and -20b) that target ephrin-B2 and EPHB4 in human placenta. Journal of Clinical Endocrinology and Metabolism 97:1051-1059. https://doi. org/10.1210/jc.2011-3131

Wander, P.L., Boyko, E.J., Hevner, K., Parikh, V.J., Tadesse, M. G., Sorensen, T. K., Williams, M. A., and Enquobahrie, D. A. 2017. Circulating early- and mid-pregnancy microRNAs and risk of gestational diabetes. Diabetes Research and Clinical Practice 132:1-9. https://doi. org/10.1016/j.diabres.2017.07.024

Weedon-Fekjær, M. S., Sheng, Y., Sugulle, M., Johnsen, G. M., Herse, F., Redman, C.W., Lyle, R., Dechend, R., and Staff, A. C. 2014. Placental miR-1301 is dysregulated in early-onset preeclampsia and inversely correlated with maternal circulating leptin. Placenta 35:709-717. https:// doi.org/10.1016/j.placenta.2014.07.002

Winger, E. E., Reed, J. L., and Ji, X. 2017. Early first trimester peripheral blood cell microRNA predicts risk of preterm delivery in pregnant women: Proof of concept. PLOS ONE 12:1-13. https://doi.org/10.1371/journal.pone.0180124

Wu, L., Song, W. Y., Xie, Y., Hu, L. L., Hou, X. M., Wang, R., Gao, Y., Zhang, J. N., Zhang, L., Li, W. W., Zhu, C., Gao, Z. Y., and Sun, Y.P. 2018. MiR-181a-5p suppresses invasion and migration of HTR-8/SVneo cells by directly targeting IGF2BP2 article. Cell Death and Disease 9. https://doi. org/10.1038/s41419-017-0045-0

Wu, L., Zhou, H., Lin, H., Qi, J., Zhu, C., Gao, Z., and Wang, H. 2012. Circulating microRNAs are elevated in plasma from severe preeclamptic pregnancies. Reproduction 143:389-397. https://doi.org/10.1530/REP-11-0304

Xiang, Y., Zhang, X., Li, Q., Xu, J., Zhou, X., Wang, T., Xing, Q., Liu, Y., Wang, L., He, L., and Zhao, X. 2013. Promoter hypomethylation of TIMP3 is associated with pre-eclampsia in a Chinese population. Molecular Human Reproduction 19:153-159. https://doi.org/10.1093/molehr/ gas054

Xu, P., Zhao, Y., Liu, M., Wang, Y., Wang, H., Li, Y. X., Zhu, X., Yao, Y., Wang, H., Qiao, J., Ji, L., and Wang, Y. L. 2014. Variations of microRNAs in human placentas and plasma from preeclamptic pregnancy. Hypertension 63:1276-1284. https://doi.org/10.1161/HYPERTENSIONAHA.113.02647

Yang, Q., Lu, J., Wang, S., Li, H., Ge, Q., and Lu, Z. 2011. Application of next-generation sequencing technology to profile the circulating microRNAs in the serum of preeclampsia versus normal pregnant women. Clinica Chimica Acta 412:2167-2173. https://doi.org/10.1016/j. cca.2011.07.029 
Yang, S., Li, H., Ge, Q., Guo, L., and Chen, F. 2015. Deregulated microRNA species in the plasma and placenta of patients with preeclampsia. Molecular Medicine Reports 12:527-534. https://doi.org/10.3892/mmr.2015.3414

Yang, X., Zhang, J., and Ding, Y. 2017. Association of microRNA-155, interleukin 17A, and proteinuria in preeclampsia. Medicine (United States) 96:1-8. https://doi. org/10.1097/MD.0000000000006509

Yoffe, L., Gilam, A., Yaron, O., Polsky, A., Farberov, L., Syngelaki, A., Nicolaides, K., Hod, M., and Shomron, N. 2018. Early Detection of Preeclampsia Using Circulating Small non-coding RNA. Scientific Reports 8:1-11. https://doi. org/10.1038/s41598-018-21604-6

Yu, G., Wang, L. G., Han, Y., and He, Q. Y. 2012. ClusterProfiler: An $\mathrm{R}$ package for comparing biological themes among gene clusters. OMICS A Journal of Integrative Biology 16:284-287. https://doi.org/10.1089/omi.2011.0118

Yu, G., Wang, L., Yan, G., and He, Q. 2014. DOSE: an R/Bioconductor package for Disease Ontology Semantic and Enrichment analysis. Bioinformatics 31(4):608-609. https:// doi.org/10.1093/bioinformatics/btu684

Zeng, F., Zhu, S., Wong, M. C. S., Yang, Z., Tang, J., Li, K., and $\mathrm{Su}, \mathrm{X} .2016$. Associations between nitric oxide synthase 3 gene polymorphisms and preeclampsia risk: A meta-analysis. Scientific Reports 6:23407. https://doi. org/10.1038/srep23407

Zhang, C., Li, Q., Ren, N., Li, C., Wang, X., Xie, M., Gao, Z., Pan, Z., Zhao, C., Ren, C., and Yang, W. 2015. Placental miR-106a 363 cluster is dysregulated in preeclamptic placenta. Placenta 36:250-252. https://doi.org/10.1016/j. placenta.2014.11.020

Zhang, Y., Diao, Z., Su, L., Sun, H., Li, R., Cui, H., and Hu, Y. 2010. MicroRNA-155 contributes to preeclampsia by down- regulating CYR61. American Journal of Obstetrics and Gynecology 202:466.e1-466.e7. https://doi.org/10.1016/j. ajog.2010.01.057

Zhou, C., Zou, Q. Y., Li, H., Wang, R. F., Liu, A. X., Magness, R. R., and Zheng, J. 2017. Preeclampsia downregulates MicroRNAs in fetal endothelial cells: Roles of miR-29a/c-3p in endothelial function. Journal of Clinical Endocrinology and Metabolism 102:3470-3479. https://doi.org/10.1210/ jc.2017-00849

Zhou, X., Li, Q., Xu, J., Zhang, X., Zhang, H., Xiang, Y., Fang, C., Wang, T., Xia, S., Zhang, Q., Xing, Q., He, L., Wang, L., Xu, M., and Zhao, X. 2016. The aberrantly expressed miR-193b-3p contributes to preeclampsia through regulating transforming growth factor- $\beta$ signaling. Scientific Reports 6:1-13. https://doi.org/10.1038/srep19910

Zhu, X., Han, T., Sargent, I. L., Yin, G., and Yao, Y. 2009. Differential expression profile of microRNAs in human placentas from preeclamptic pregnancies vs normal pregnancies. American Journal of Obstetrics and Gynecology 200:661.e1-661.e7. https://doi.org/10.1016/j. ajog.2008.12.045

Zhu, X., Han, T., Wang, X., Li, Y., Yang, H., Luo, Y., Yin, G., and Yao, Y. 2010. Overexpression of miR-152 leads to reduced expression of human leukocyte antigen-G and increased natural killer cell mediated cytolysis in JEG-3 cells. American Journal of Obstetrics and Gynecology 202:592.e1-592. e7. https://doi.org/10.1016/j.ajog.2010.03.002

Zhu, X., Yang, Y., Han, T., Yin, G., Gao, P., Ni, Y., Su, X., Liu, Y., and Yao, Y. 2015. Suppression of microRNA-18a expression inhibits invasion and promotes apoptosis of human trophoblast cells by targeting the estrogen receptor a gene. Molecular Medicine Reports 12:2701-2706. https:// doi.org/10.3892/mmr.2015.3724 


\section{SUPPLEMENTS}

\section{Supplement 1. Differentially expressed miRNAs in studies with miR-210 associated with pre-eclampsia}

\begin{tabular}{|c|c|c|c|c|}
\hline Trimester & $\begin{array}{c}\text { Type of } \\
\text { biomaterial }\end{array}$ & Upregulated & Downregulated & Reference \\
\hline 1 & serum & $\begin{array}{l}\text { miR-25, miR-32, miR-152, miR- } \\
\text { 193a-3p, miR-204, miR-210, miR- } \\
\text { 215, miR-296-5p, miR-518b, miR- } \\
\text { 650, miR-520a, miR-1233 }\end{array}$ & $\begin{array}{l}\text { miR-15b, miR-126, miR-144, miR- } \\
\text { 335, miR-376a, miR-668 }\end{array}$ & $\begin{array}{l}\text { Ura B, Feriotto G, Monasta L et al } \\
\text { (2014) Taiwan J Obstet Gynecol. }\end{array}$ \\
\hline 2 & serum & miR-152, miR-183, miR-210 & & $\begin{array}{l}\text { Li Q, Long A, Jiang L et al (2015) } \\
\text { Biomedical Reports }\end{array}$ \\
\hline $2-3$ & serum & $\begin{array}{l}\text { miR-210, miR-210-5p, miR-574-5p, } \\
\text { miR-1233 }\end{array}$ & & $\begin{array}{l}\text { Munaut C, Tebache L, Blacher S et } \\
\text { al (2016) Biomedical Reports. }\end{array}$ \\
\hline \multirow[t]{10}{*}{3} & serum & $\begin{array}{l}\text { miR-152, miR-182, miR-183, miR- } \\
210\end{array}$ & & $\begin{array}{l}\text { Li Q, Long A, Jiang L et al (2015) } \\
\text { Biomedical Reports. }\end{array}$ \\
\hline & serum & miR-210 & & $\begin{array}{l}\text { Gunel T, Zeybek YG, Akçakaya P et } \\
\text { al (2011) Genet Mol Res. }\end{array}$ \\
\hline & plasma & $\begin{array}{l}\text { miR-21, miR-155, miR-210, miR- } \\
\text { 215, miR-650 }\end{array}$ & miR-18a, miR-19b1 & $\begin{array}{l}\text { Jairajpuri DS, Malalla ZH, } \\
\text { Mahmood N et al (2017) Gene. }\end{array}$ \\
\hline & placenta & miR-210 & $\begin{array}{l}\text { miR-1, miR-34c-5p, miR-139-5p, } \\
\text { miR-328, miR-500, miR-584, miR- } \\
1247\end{array}$ & $\begin{array}{l}\text { Enquobahrie DA, Abetew DF, } \\
\text { Sorensen TK et al. (2011) Am J } \\
\text { Obstet Gynecol. }\end{array}$ \\
\hline & placenta & miR-182, miR-210 & $\begin{array}{l}\text { miR-7, miR-101, miR-128, miR- } \\
\text { 140-5p, miR-196b, miR-199b-5p, } \\
\text { miR-223, miR-363, miR-493, miR- } \\
\text { 520c-3p, miR-520f, miR-551b, } \\
\text { miR-585 }\end{array}$ & $\begin{array}{l}\text { Betoni JS, Derr K, Pahl MC et al. } \\
\text { (2013) Hypertens Pregnancy. }\end{array}$ \\
\hline & placenta & $\begin{array}{l}\text { miR-10b, miR-18a, miR-19a, miR- } \\
\text { 20a, miR-22, miR-126, miR-142- } \\
\text { 3p, miR-144, miR-146b-5p, miR- } \\
\text { 185, miR-193b, miR-210, miR-451, } \\
\text { miR-517c, miR-518c, miR-518f, } \\
\text { miR-519e, miR-520a-3p, miR-525- } \\
\text { 5p, miR-526b, miR-590-5p }\end{array}$ & miR-224 & $\begin{array}{l}\text { Ishibashi O, Ohkuchi A, Ali MM et } \\
\text { al. (2012) Hypertension. }\end{array}$ \\
\hline & placenta & $\begin{array}{l}\text { miR-17, miR-21, miR-96, miR- } \\
\text { 135a, miR-152, miR-181a, miR- } \\
\text { 182, miR-210, miR-335, miR-451a, } \\
\text { miR-516, miR-584 }\end{array}$ & $\begin{array}{l}\text { miR-32, miR-126, miR-196, miR- } \\
\text { 362-3p, miR-377 }\end{array}$ & $\begin{array}{l}\text { Jiang F, Li J, Wu G et al. (2015) Mol } \\
\text { Med Rep. }\end{array}$ \\
\hline & placenta & miR-210 & $\begin{array}{l}\text { miR-1301, miR-223-3p, miR-224- } \\
5 p\end{array}$ & $\begin{array}{l}\text { Weedon-Fekjaer MS, Sheng Y, } \\
\text { Sugulle M et al (2014) Placenta. }\end{array}$ \\
\hline & placenta & $\begin{array}{l}\text { miR-154, miR-155, miR-181b, miR- } \\
\text { 182, miR-183, miR-200b, miR-210 }\end{array}$ & & $\begin{array}{l}\text { Pineles BL, Romero R, } \\
\text { Montenegro D et al. (2007) Am J } \\
\text { Obstet Gynecol. }\end{array}$ \\
\hline & placenta & $\begin{array}{l}\text { miR-30a-3p, miR-152, miR-181a, } \\
\text { miR-210, miR-296, miR-362, miR- } \\
\text { 517, miR-518b, miR-519e, miR- } \\
\text { 584, miR-638 }\end{array}$ & $\begin{array}{l}\text { miR-1, miR-18a, miR-19a, miR- } \\
\text { 18b, miR-10b, miR-32, miR-101, } \\
\text { miR-126, miR-144, miR-154, miR- } \\
\text { 150, miR-195, miR-204, miR-218, } \\
\text { miR-223, miR-363, miR-374, miR- } \\
\text { 377, miR-411, miR-450, miR-542- } \\
\text { 3p, miR-590, miR-625 }\end{array}$ & $\begin{array}{l}\text { Zhu XM, Han T, Sargent IL et al } \\
\text { (2009) Am J Obstet Gynecol. }\end{array}$ \\
\hline
\end{tabular}




\begin{tabular}{|c|c|c|c|c|}
\hline Trimester & $\begin{array}{c}\text { Type of } \\
\text { biomaterial }\end{array}$ & Upregulated & Downregulated & Reference \\
\hline & placenta & $\begin{array}{l}\text { miR-515-3p, miR-31, miR-210, } \\
\text { miR-518a, miR-524, miR-518c, } \\
\text { miR-520a, miR-515-5p, miR- } \\
\text { 516a-5p, miR-519e, miR-193b, } \\
\text { miR-4532, miR-518f, miR-527, } \\
\text { miR-518e }\end{array}$ & $\begin{array}{l}\text { miR-195, miR-223, miR-1, miR-34c, } \\
\text { miR-let-7f, miR-98, miR-135b }\end{array}$ & $\begin{array}{l}\text { Vashukova ES, Glotov AS, Fedotov } \\
\text { PV et al (2016) Mol Med Rep. }\end{array}$ \\
\hline & placenta & $\begin{array}{l}\text { miR-30a-3p, miR-524, miR-17-3p, } \\
\text { miR-151, miR-193b, miR-210, } \\
\text { miR-518b }\end{array}$ & $\begin{array}{l}\text { miR-195, miR-223, miR-218, miR- } \\
\text { 17, miR-18a, miR-19b1, miR-92a1, } \\
\text { miR-379, miR-411 }\end{array}$ & $\begin{array}{l}\text { Xu P, Zhao Y, Liu M et al (2014) } \\
\text { Hypertension. }\end{array}$ \\
\hline & placenta & $\begin{array}{l}\text { miR-20a, miR-19b, miR-424, miR- } \\
\text { 125b-1-3p, miR-355, miR-1469, } \\
\text { miR-181a, miR-210, miR-1, miR- } \\
\text { 16, miR-182 }\end{array}$ & $\begin{array}{l}\text { miR-29a-3p, miR-200c, miR-744, } \\
\text { miR-1826, miR-584, miR-363, } \\
\text { miR-335 }\end{array}$ & $\begin{array}{l}\text { Zhang C, Li Q, Ren N et al (2015) } \\
\text { Placenta. }\end{array}$ \\
\hline & placenta & $\begin{array}{l}\text { miR-193b-5p, miR-193b-3p, miR- } \\
\text { 210-5p, miR-210-3p, miR-365a-3p, } \\
\text { miR-365b-3p, miR-181a-2-3p, miR- } \\
\text { 365a-5p, miR-27a-5p, miR-33b-3p, } \\
\text { miR-520a-3p }\end{array}$ & & $\begin{array}{l}\text { Awamleh Z, Gloor GB, Han VKM } \\
\text { (2019) BMC Med Genomics }\end{array}$ \\
\hline
\end{tabular}




\section{Supplement 2. Differentially expressed miRNAs without miR-210 associated with pre-eclampsia}

\begin{tabular}{|c|c|c|c|c|}
\hline Trimester & $\begin{array}{c}\text { Type of } \\
\text { biomaterial }\end{array}$ & Upregulated & Downregulated & Reference \\
\hline 1 & plasma & miR-221, miR-4433b, miR-let-7g & $\begin{array}{l}\text { miR-10b, miR-25, miR-99b, miR- } \\
\text { 143, miR-151a, miR-182, miR-191, } \\
\text { miR-146b, miR-486 }\end{array}$ & $\begin{array}{l}\text { Yoffe L, Gilam A, Yaron O et al } \\
\text { (2018) Scientific Reports. }\end{array}$ \\
\hline 2 & serum & $\begin{array}{l}\text { miR-512-3p, miR-518f-3p, miR- } \\
\text { 520d-3p, miR-520c-3p }\end{array}$ & & $\begin{array}{l}\text { Martinez-Fierro ML, Garza-Veloz } \\
\text { I, Gutierrez-Arteaga C et al (2018) } \\
\text { Arch Gynecol Obstet. }\end{array}$ \\
\hline \multirow[t]{12}{*}{3} & plasma & miR-1183 & & $\begin{array}{l}\text { Gunel T, Hosseini MK, Gumusoglu } \\
\text { E et al (2017) Placenta. }\end{array}$ \\
\hline & serum & $\begin{array}{l}\text { miR-29a, miR-125a-5p, miR-125b, } \\
\text { miR-136, miR-517b, miR-517c, } \\
\text { miR-518e, miR-519d, miR-519a, } \\
\text { miR-520h, miR-520g, miR-521, } \\
\text { miR-542-3p, miR-let-7a-star, miR- } \\
\text { let-7f-1-star }\end{array}$ & $\begin{array}{l}\text { miR-185, miR-223, miR-320c, } \\
\text { miR-1260, miR-1272, miR-let-7d, } \\
\text { miR-let-7f }\end{array}$ & $\begin{array}{l}\text { Yang Q, Lu J, Wang S et al (2011) } \\
\text { Clin Chim Acta. }\end{array}$ \\
\hline & plasma & $\begin{array}{l}\text { miR-10a, miR-15b*, miR-18a, miR- } \\
\text { 19a, miR-21, miR-23a, miR-23b, } \\
\text { miR-24, miR-26b, miR-27a, miR- } \\
\text { 29a, miR-29b, miR-29c, miR-30a, } \\
\text { miR-30b, miR-34a, miR-99a, miR- } \\
\text { 100, miR-101, miR-114, miR-125a- } \\
\text { 5p, miR-125b, miR-130a, miR-144, } \\
\text { miR-145, miR-182, miR-199a-5p, } \\
\text { miR-221, miR-299a-5p, miR-378, } \\
\text { miR-424, miR-512-5p, miR-515-3p, } \\
\text { miR-517b, miR-517c, miR-518b, } \\
\text { miR-518c, miR-519a, miR-519d, } \\
\text { miR-519e, miR-520h, miR-521, } \\
\text { miR-525-3p }\end{array}$ & $\begin{array}{l}\text { miR-15b, miR-19b, miR-25, miR- } \\
\text { 107, miR-185, miR-223, miR-320c, } \\
\text { miR-451, miR-let-7f }\end{array}$ & $\begin{array}{l}\text { Li H, Ge Q, Guo L et al (2013) } \\
\text { Biomed Res Int. }\end{array}$ \\
\hline & serum & miR-155 & & $\begin{array}{l}\text { Xu Yang, Yiling Ding et al. (2017) } \\
\text { Medicine (Baltimore) }\end{array}$ \\
\hline & plasma & miR-206-5p & & $\begin{array}{l}\text { Akehurst C, Small HY, } \\
\text { Sharafetdinova L et al (2015) J } \\
\text { Hypertens. }\end{array}$ \\
\hline & plasma & $\begin{array}{l}\text { miR-24, miR-26a, miR-103, miR- } \\
\text { 130b, miR-181a, miR-342-3p, } \\
\text { miR-574-5p }\end{array}$ & & $\begin{array}{l}\text { Wu L, Zhou H, Lin H et al (2012) } \\
\text { Reproduction. }\end{array}$ \\
\hline & plasma & miR-346, miR-582-3p & & $\begin{array}{l}\text { Pei-Yin Tsai, Mei-Tsz Su et al. } \\
\text { (2017) Int J Mol Sci }\end{array}$ \\
\hline & plasma & $\begin{array}{l}\text { miR-423-5p, miR-519a-3p, miR- } \\
\text { 629-5p, miR-let-7c-5p }\end{array}$ & & $\begin{array}{l}\text { Timofeeva AV, Gusar VA, Kan NE } \\
\text { et al (2018) Placenta. }\end{array}$ \\
\hline & plasma & $\begin{array}{l}\text { miR-18a, miR-18b, miR-27a, miR- } \\
\text { 29a, miR-93, miR-126, miR-130a, } \\
\text { miR-135b, miR-142-3p, miR-149, } \\
\text { miR-188-5p, miR-203, miR-205, } \\
\text { miR-224, miR-301a, miR-517c, } \\
\text { miR-518a-3p, miR-518e, miR-519d }\end{array}$ & & $\begin{array}{l}\text { Yang S, Li H, Ge Q et al (2015) Mol } \\
\text { Med Rep. }\end{array}$ \\
\hline & plasma & miR-885-5p & & $\begin{array}{l}\text { Sandrim V, Luizon M, Palei A et al } \\
\text { (2016) BJOG. }\end{array}$ \\
\hline & plasma & & $\begin{array}{l}\text { miR-23c, miR-425, miR-let-7b, } \\
\text { miR-let-7f-1 }\end{array}$ & $\begin{array}{l}\text { Gunel T, Hosseini MK, Gumusoglu } \\
\text { E et al (2017) Placenta. }\end{array}$ \\
\hline & placenta & $\begin{array}{l}\text { miR-125b, miR-126, miR-130a, } \\
\text { miR-141, miR-223, miR-517a, miR- } \\
\text { 517c, miR-518e }\end{array}$ & $\begin{array}{l}\text { miR-22, miR-29c, miR-30d, miR- } \\
\text { 143, miR-518b, miR-525 }\end{array}$ & $\begin{array}{l}\text { Guo L, Yang Q, Lu J et al. (2011) } \\
\text { PLoS ONE. }\end{array}$ \\
\hline
\end{tabular}




\begin{tabular}{|c|c|c|c|c|}
\hline Trimester & $\begin{array}{c}\text { Type of } \\
\text { biomaterial }\end{array}$ & Upregulated & Downregulated & Reference \\
\hline & placenta & $\begin{array}{l}\text { miR-16, miR-20b, miR-26b, miR- } \\
\text { 27a, miR-29b, miR-30e, miR-126, } \\
\text { miR-141, miR-181a, miR-195, } \\
\text { miR-222, miR-335, miR-450a, } \\
\text { miR-451, miR-486-3p, miR-519b- } \\
\text { 3p, miR-520g, miR-522, miR-565, } \\
\text { miR-7f }\end{array}$ & $\begin{array}{l}\text { miR-214, miR-423-5p, miR-491-5p, } \\
\text { miR-508-5p, miR-523-3p, miR-612, } \\
\text { miR-658 }\end{array}$ & $\begin{array}{l}\text { Hu Y, Li P, Hao S et al. (2009) Clin } \\
\text { Chem. }\end{array}$ \\
\hline & placenta & $\begin{array}{l}\text { miR-18a, miR-18b, miR-27a, miR- } \\
\text { 29a, miR-93, miR-126, miR-130a, } \\
\text { miR-135b, miR-142-3p, miR-149, } \\
\text { miR-188-5p, miR-203, miR-205, } \\
\text { miR-224, miR-301a, miR-517c, } \\
\text { miR-518a-3p, miR-518e, miR-519d }\end{array}$ & & $\begin{array}{l}\text { Yang S, Li H, Ge Q et al (2015) Mol } \\
\text { Med Rep. }\end{array}$ \\
\hline & placenta & $\begin{array}{l}\text { miR-20b, miR-512-3p, miR-516a- } \\
\text { 5p, miR-524-3p, miR-2277 }\end{array}$ & $\begin{array}{l}\text { miR-34c-5p, miR-146a, miR-151- } \\
\text { 3p, miR-192 }\end{array}$ & $\begin{array}{l}\text { Wang W, Feng L, Zhang H et al } \\
\text { (2012) J Clin Endocrinol Metab. }\end{array}$ \\
\hline & placenta & & $\begin{array}{l}\text { miR-10b, miR-18b, miR-21, miR- } \\
\text { 23, miR-23c, miR-30c-1, miR-33b, } \\
\text { miR-125a-3b, miR-191, miR-345, } \\
\text { miR-370, miR-422a, miR-425, } \\
\text { miR-509-3-5p, miR-513b, miR- } \\
\text { 550a, miR-614, miR-650, miR-662, } \\
\text { miR-718, miR-933, miR-1225-3p, } \\
\text { miR-1273c, miR-1275, miR-1539, } \\
\text { miR-2116, miR-3162, miR-3180- } \\
\text { 5p, miR-let-7b, miR-let-7f-1 }\end{array}$ & $\begin{array}{l}\text { Gunel T, Hosseini MK, Gumusoglu } \\
\text { E et al (2017) Placenta }\end{array}$ \\
\hline & placenta & $\begin{array}{l}\text { miR-25, miR-26a, miR-26b, miR- } \\
\text { 92b, miR-95, miR-191, miR-197, } \\
\text { miR-198, miR-202, miR-204, miR- } \\
\text { 296-5p, miR-296-3p, miR-342-3p }\end{array}$ & miR-21, miR-223 & $\begin{array}{l}\text { Choi SY, Yun J, Lee OJ et al. (2013) } \\
\text { Placenta. }\end{array}$ \\
\hline & placenta & & miR-346, miR-582-3p & $\begin{array}{l}\text { Pei-Yin Tsai, Mei-Tsz Su et al. } \\
\text { (2017) Int J Mol Sci }\end{array}$ \\
\hline & placenta & miR-155 & & $\begin{array}{l}\text { Xu Yang, Yiling Ding et al. (2017) } \\
\text { Medicine (Baltimore) }\end{array}$ \\
\hline & placenta & $\begin{array}{l}\text { miR-223, miR-378, miR-431, miR- } \\
\text { 493, miR-496, miR-720 }\end{array}$ & $\begin{array}{l}\text { miR-24, miR-30d, miR-146b-5p, } \\
\text { miR-145, miR-146a, miR-181d, } \\
\text { miR-495, miR-512-3p, miR-517a, } \\
\text { miR-518b, miR-539, miR-526b, } \\
\text { miR-654-3p, miR-let-7e, }\end{array}$ & $\begin{array}{l}\text { Mayor-Lynn K, Toloubeydokhti T, } \\
\text { Cruz AC et al (2011) Reprod Sci. }\end{array}$ \\
\hline & placenta & $\begin{array}{l}\text { miR-124, miR-130b, miR-155*, } \\
\text { miR-302c, miR-367, miR-383, miR- } \\
\text { 431, miR-455-5p, miR-500a, miR- } \\
\text { 518a-5p, miR-875-3p, miR-1183, } \\
\text { miR-1197, miR-1204, miR-1305, } \\
\text { miR-1914, miR-1915, miR-3143, } \\
\text { miR-3157, miR-3186-5p, miR- } \\
\text { 3200-5p, miR-3616-5p, miR-3670, } \\
\text { miR-3928, miR-3941 }\end{array}$ & $\begin{array}{l}\text { miR-30a, miR-103-2, miR-126, } \\
\text { miR-412, miR-516a-3p, miR-548o, } \\
\text { miR-631, miR-19a, miR-542-3p, } \\
\text { miR-544b, miR-548w, miR-663b, } \\
\text { miR-885-3p, miR-1248, miR-3652, } \\
\text { miR-3942, miR-3943 }\end{array}$ & $\begin{array}{l}\text { Lykoudi A, Kolialexi A, Lambrou GI } \\
\text { et al (2018) Placenta. }\end{array}$ \\
\hline & placenta & & $\begin{array}{l}\text { miR-127-3p, miR-423-5p, miR- } \\
\text { 519a-3p, miR-532-5p, miR-539-5p, } \\
\text { miR-629-5p, miR-let-7c-5p }\end{array}$ & $\begin{array}{l}\text { Timofeeva AV, Gusar VA, Kan NE } \\
\text { et al (2018) Placenta. }\end{array}$ \\
\hline & placenta & $\begin{array}{l}\text { miR-104, miR-128a, miR-133b, } \\
\text { miR-182, miR-302, miR-let-7b }\end{array}$ & & $\begin{array}{l}\text { Noack F, Ribbat-Idel J, Thorns C } \\
\text { et al (2011) Journal of Perinatal } \\
\text { Medicine. }\end{array}$ \\
\hline & cord plasma & & miR-346 & $\begin{array}{l}\text { Pei-Yin Tsai, Mei-Tsz Su et al. } \\
\text { (2017) Int J Mol Sci }\end{array}$ \\
\hline
\end{tabular}

